\title{
HEAVY METAL ANALYSIS OF BLEPHARIS MADERASPATENSIS (L.) HEYNE EX ROTH
}

\author{
VIJAYALAKSHMI S, KRIPA KG* \\ Department of Biochemistry, School of Life Sciences, Vels Institute of Science, Technology and Advanced Studies, Chennai, Tamil Nadu, \\ India. Email: kgkripa.sls@velsuniv.ac.in \\ Received: 03 April 2018, Revised and Accepted: 15 June 2018
}

ABSTRACT

Objective: The objective of the study was to execute systematic heavy metal assessment of the plant to ensure its safe usage in herbal medicine or as nutraceuticals. Blepharis maderaspatensis (L.)Heyne ex Roth commonly called as Nethiramooli in Tamil is a widely distributed medicinal herb with a long history of traditional usage in the treatment of many ailments.

Method: The plant material was collected from Thanjavur, Tamil Nadu, India, duly authenticated and heavy metal content investigated by inductively coupled plasma optical emission spectrometry.

Results: Results indicated that the toxic metal, mercury was not detectable even in traces; other metals such as cadmium, chromium, molybdenum, manganese, nickel, and lead were found at very low quantities while trace elements such as iron, zinc, copper, and cobalt in fairly significant concentrations.

Conclusions: These results thus substantiate the safe usage of this plant and may be used to set new standards for prescribing the dosage of the herbal drugs prepared from it, ensuring a better understanding of the risks associated with its usage.

Keywords: Blepharis maderaspatensis, Herbal drug, Heavy metal toxicity, Heavy metal analysis, Inductively coupled plasma optical emission spectrometry.

(C) 2018 The Authors. Published by Innovare Academic Sciences Pvt Ltd. This is an open access article under the CC BY license (http://creativecommons. org/licenses/by/4. 0/) DOI: http://dx.doi.org/10.22159/ajpcr.2018.v11i10.26418

\section{INTRODUCTION}

Plants serve as a source of medicine for people all over the world [1]. The principal systems of medicine practiced in India include Ayurveda, Siddha, and Unani-Tibb. These systems utilize drugs of natural origin constituting plants, animals, and mineral preparations [2]. Herbal medicines include herbs, herbal materials, herbal preparations, and finished herbal products. Herbs include crude plant material such as leaves, flowers, fruit, seeds, stems, wood, bark, roots, rhizomes, or other plant parts, which may be entire, fragmented, or powdered [3]. There are reports indicating undesirable side effects due to long-term consumption of these medicines without proper advice that may be due to the presence/accumulation of heavy metals. Any toxic metal may be called heavy metal, irrespective of their atomic mass or density [4]. The term "heavy metal" refers to natural metallic elements with a density $>5 \mathrm{~g} / \mathrm{cm}^{3}$. Heavy metals belong to a set of ill-defined subset of elements that exhibit metallic properties. These include the transition metals, some metalloids, lanthanides, and actinides [5].

Plants usually accumulate heavy metals by absorbing them from the soil in which they grow. This includes elements such as mercury $(\mathrm{Hg})$, lead $(\mathrm{Pb})$, arsenic $(\mathrm{As})$, cadmium (Cd), copper (Cu), nickel (Ni), zinc ( $\mathrm{Zn})$, cobalt (Co), manganese (Mn), chromium (Cr), iron (Fe), and Antimony (Sb) [6]. Plants are the main link in the transfer of heavy metals from the contaminated soil to humans. Heavy metals consist of both biological and non-biological essential metals. Biological essential heavy metals include $\mathrm{Co}, \mathrm{Cu}, \mathrm{Cr}, \mathrm{Fe}$, magnesium (Mg), $\mathrm{Mn}$, molybdenum (Mo), $\mathrm{Ni}$, selenium, and $\mathrm{Zn}$ that are essential nutrients required for various biochemical and physiological functions [7]. Non-biological essential heavy metals exhibit negative effects of acute and chronic toxicity even when present in very low concentrations [8], and these non-essential heavy metals include $\mathrm{Cd}, \mathrm{Pb}, \mathrm{Hg}$, and As especially prevalent in nature due to their high industrial use. These metals serve no biological function, and their presence in tissues reflects contact of the organism with its environment. They are toxic even at low doses $[9,10]$.

Blepharis maderaspatensis (L.)Heyne ex Roth belongs to the family Acanthaceae., other names of the plant are Kodali soppu (Kannada), Elumbotti (Malayalam), and Kooravaal Chedi, and Kozhimookkan
(Tamil). This plant exhibits increased potency as internal and external medicine. The aerial parts of the plant are considered an indigenous remedy for wounds and fusion of broken bones by the tribal people of Tamil Nadu [11]. Other traditional uses of this plant include the usage of plant ash for dropsy, swellings, edema, gout, dry alcoholic extracts as potent diuretic, and crushed and mixed plant parts for venereal diseases. The juice of leaves may be administered for throat troubles and asthma; leaf paste ground with egg and onion applied for bone fractures [12]. Further, antioxidant [13], antimicrobial [14], anti-inflammatory, and antinociceptive [15] properties have also been proved. However, there is an inbuilt health risk associated with many herbal plants due to the presence of harmful heavy metals. The World Health Organization has already made it compulsory that before exporting, herbal products should be tested for their heavy metal content so that heavy metals remain within permissible limits [16]. Still systematic study and reports on the mineral composition of many indigenous plant foods are to be established [17]. It is imperative, therefore, to study the heavy metal contents in the plant material before human consumption and eventually it has become mandatory for Ayurvedic and Siddha preparations/formulations to enlist and detail their elemental contents [18]. Hence, the biosorption concentration of the different elements in the dry powder of ariel parts of Blepharis maderaspatensis (L.) Heyne ex Roth was studied using the inductively coupled plasma - optical emission spectroscopy (ICP-OES).

\section{METHODS}

\section{Collection of the sample}

The Aerial parts (excluding flowers) of B. maderaspatensis (L.) Heyne ex Roth were collected from Thanjavur, Tamil Nadu, India. About 100 gm of the plant sample was weighed and washed thoroughly with distilled water. Subsequently, it was dried in the shade to remove the moisture content associated with the plant material and powder. The particles with size $<1 \mathrm{~mm}$ were sieved and collected for further analysis.

Collection and authentification of plant materials

As the plant has been widely used in food and therapeutics, there is a need for authentication and standardization of the plant material [19]. The plant was taxonomically identified by 
Dr. Jayaraman, Plant Taxonomist, PARC, Tambaram, Chennai (Voucher specimen:PARC/2016/3248).

\section{Instrumentation}

The traces of heavy metals were detected through ICP-OES. ICP-OES is a spectroscopic technique suitable for detection and quantification of trace elements in plant samples. The technique is based on the unprompted emission of photons from atoms and ions that have been excited in a radiofrequency discharge [20].

\section{Chemicals}

Chemicals used were of analytical grade (Sigma and Merck). Deionized double distilled water was used to prepare all solutions.

\section{Stock solution}

The spike stock solution was prepared from the same stocks as the calibration standards using the $2 \% \mathrm{HNO}_{3}$ and $0.5 \% \mathrm{HCl}$ acid matrix. Stock solutions of metal ions were prepared from their nitrate salts. The working standards for all metals studied were prepared by dissolving an appropriate amount of metallic salts in deionized water

\section{Sample preparation}

The Thermo-iCAP 6000 Series model was used for ICP-OES heavy metal analysis. The instrument was calibrated with multi-element standard solution in $2 \% \mathrm{HNO}_{3}$. The concentration ranges of calibration samples in $\mu \mathrm{g} \mathrm{ml}^{-1}$ were As $-0-0.2$, Cd $-0-4$, Co - 0-15, Cr - 0-15, Cu - 0-50, $\mathrm{Fe}-100-800$, Mo - 0-5, Mn - 0-15, Ni-0-15, Pb - 0-15, Zn - 0-50, and $\mathrm{Hg}-0-50$. The plant samples were ashed in muffle furnace following Bulgarian standard $17365-94$. The $0.5 \mathrm{~g}$ sample was heated stepwise to up to $350^{\circ} \mathrm{C}$ for $4 \mathrm{~h}$. The same was ashed at $525^{\circ} \mathrm{C}$ for $1 \mathrm{~h}$. After cooling the ashes of the plant, samples were dissolved in $20 \mathrm{ml}$ of $1.5 \% \mathrm{HNO}_{3}$, and it then analyzed [20].

Quality control and assurance protocols were carried out to ensure accuracy and reliability of the results. Estimations were performed in triplicates and result duly represented as mean \pm standard deviation of three determinations.

\section{RESULTS}

Quantitative determination of 12 elements inclusive of $\mathrm{Hg}, \mathrm{Cr}, \mathrm{Mo}, \mathrm{Mn}$, $\mathrm{Ni}, \mathrm{Pb}, \mathrm{Fe}, \mathrm{Zn}, \mathrm{Cu}, \mathrm{Co}, \mathrm{As}$, and $\mathrm{Sb}$ in the Aerial parts of $B$. maderaspatensis (L.) Heyne ex Roth (excluding flowers) was analyzed in this study using ICP-OES. The acceptable limits for the various elements were studied and compared with the measured values. Since the benefit of metal residues in pharmaceutical products is uncertain unless administered therapeutically, they should be removed to the extent possible to meet product specifications, good manufacturing practices, or other quality-based criteria [21]. The reference values for normal and toxic concentrations of heavy metals in plants have been shown in Table 1.

ICP-OES determination of elemental contents of B. maderaspatensis ( $L$.) Heyne ex Roth indicated the presence of nine elements $\mathrm{Cu}, \mathrm{Ni}, \mathrm{Pb}, \mathrm{Cr}$, $\mathrm{Mn}, \mathrm{Zn}, \mathrm{Mo}, \mathrm{Co}$, and Fe to be present in substantial amounts and within permissible limits. Non-essential heavy metals including $\mathrm{Hg}$, As,, and $\mathrm{Sb}$ were not detected even in traces in the plant.

\section{DISCUSSION}

With the ever-increasing use of herbal medicines and the global expansion of the herbal medicines market, safety has become a major concern for both health authorities and the public. The World Health Organization recommends that the medicinal plants which form the raw materials for the finished products may be checked for the presence of heavy metals, pesticides, bacteria, and other contaminants [3]. Evidence from various countries implies that toxic heavy metals and undeclared prescription drugs in Asian herbal medicines might constitute a serious health problem $[22,23]$. Thus, the estimation of heavy metals is highly essential for raw drugs or plant parts used for the preparation of compound formulation drugs [24]. Numerous
Table 1: Reference values for normal and toxic concentrations of heavy metals in plants

\begin{tabular}{lll}
\hline Element & $\begin{array}{l}\text { Normal concentrations } \\
\left(\mathbf{m g ~ k g}^{-1}\right)\end{array}$ & $\begin{array}{l}\text { Toxic concentration } \\
\left(\mathbf{m g ~ k g}^{-1}\right)\end{array}$ \\
\hline $\mathrm{Cu}$ & $3-15$ & 20 \\
$\mathrm{Ni}$ & $0.1-5$ & 30 \\
$\mathrm{~Pb}$ & $1-5$ & 20 \\
$\mathrm{Hg}$ & $<0.1-0.5$ & 5 \\
$\mathrm{Cr}$ & $<0.1-1$ & 2 \\
$\mathrm{Mn}$ & $15-100$ & 400 \\
$\mathrm{Zn}$ & $15-150$ & 200 \\
$\mathrm{Mo}$ & $0.1-0.5$ & $10-50$ \\
$\mathrm{Co}$ & $0.05-0.5$ & $30-40$ \\
$\mathrm{Fe}$ & $50-250$ & $>500)$ \\
$\mathrm{As}$ & $10-60 \mathrm{c}$ & $<2$ \\
$\mathrm{Sb}$ & $<2-29$ & $5-10 \mathrm{~g}$ \\
\hline
\end{tabular}

Aleksandra Stanojkovic-Sebic et al., 2015 [20]. Cu: Copper, Ni: Nickel, Pb: Lead, Hg: Mercury, Cr: Chromium, Mn: Manganese, Zn: Zinc, Mo: Molybdenum, Co: Cobalt, Fe: Iron, As: Arsenic, Sb: Antimony

countries and several pharmacopeia references have published limits on allowable concentrations of heavy metals, stated in $\mathrm{mg} / \mathrm{kg}$ or $\mathrm{ppm}$, for finished food products, and/or dietary supplement type products, or ingredients used in these products [25].

It has also been observed that heavy metals have low excretion rates which could result in damaging effects on humans even at very low concentrations. Among heavy metals, researchers have found $\mathrm{Pb}$ to be the commonly occurring metal, followed by $\mathrm{Hg}$ and As [10]. Intense, high-dose exposure to lead causes acute symptomatic poisoning, characterized by colic, anemia, and depression of the central nervous system that may result in coma, convulsions, and death. The most critical consequence of low level lead toxicity in utero and during childhood is damage to the developing brain and nervous system. The immune, reproductive and cardiovascular systems are also adversely affected by relatively low levels of exposure to lead - that is, $<10 \mu \mathrm{g} / \mathrm{dl}$ [26]. Inorganic Hg may be found in few herbal preparations, and this may be a major toxic metal that can seriously affect the nervous system and lead to violent muscular spasms and even death. Pregnant and nursing women should also be cautious as Hg may contaminate breast milk [27]. As is also present as a contaminant in many traditional remedies and nutritional herbal supplements, can be a serious health hazard. As is carcinogenic and its exposure leads to cancer and other toxic manifestations, including cardiovascular diseases, dermal effects, renal effects, hepatic effects, hematological effects, gastrointestinal effects respiratory diseases, neurological problems, and reproductive, and developmental effects [28]. Ni has been reported to cause contact dermatitis, nasal, sinus and lung cancers, renal disorders, chronic bronchitis, acute respiratory distress syndrome, and pulmonary fibrosis. $\mathrm{Cr}$ is also known to cause nephrotoxicity, nasal and lung ulcers, and skin ulcers [18]. Users of Ayurvedic medicine may be at risk for heavy metal toxicity, and hence testing of such formulations for toxic heavy metals is made mandatory [29]. This study indicated the complete absence of $\mathrm{Pb}$, $\mathrm{Hg}$, and As in B. maderaspatensis (L.) Heyne ex Roth while Ni and Cr were present in traces, assuring its safety for human consumption.

Metals such as $\mathrm{Zn}, \mathrm{Cu}, \mathrm{Fe}$, and $\mathrm{Mn}$ are essential nutrients; they are important for the physiological and biological functions of the human body. However, an increase in their intake above certain permissible limits can also become toxic $[3,25]$. In the present analysis, the concentration of $\mathrm{Cu}, \mathrm{Ni}, \mathrm{Pb}, \mathrm{Cr}, \mathrm{Mn}, \mathrm{Zn}, \mathrm{Mo}, \mathrm{Co}$, and Fe was 1.486, 1.511, $1.109,0.005,20.19,0.730,0.001,0.065$, and $31.14 \mathrm{mg} / \mathrm{g}$, respectively (Table 2). The results indicate that all the metals are below the permissible limits. In general, a number of health problems have been linked to excessive uptake of dietary heavy metals including a decrease in immunological defenses, cardiac dysfunctions, fetal malformations, impaired psychosocial and neurological behaviors, gastrointestinal cancers, and many others [30]. Thus, on the basis of this experimental 
Table 2: Heavy metal content of B. maderaspatensis (L.) Heyne ex Roth

\begin{tabular}{ll}
\hline Elements & Observed Mean \pm SD $(\mathbf{m g})$ \\
\hline $\mathrm{Cu}$ & $1.486 \pm 0.077$ \\
$\mathrm{Ni}$ & $1.511 \pm 0.075$ \\
$\mathrm{~Pb}$ & $1.109 \pm 0.130$ \\
$\mathrm{Hg}$ & - \\
$\mathrm{Cr}$ & $0.005 \pm 0.001$ \\
$\mathrm{Mn}$ & $20.19 \pm 1.578$ \\
$\mathrm{Zn}$ & $0.730 \pm 0.114$ \\
$\mathrm{Mo}$ & $0.001 \pm 0.000$ \\
$\mathrm{Co}$ & $0.065 \pm 0.003$ \\
$\mathrm{Fe}$ & $31.14 \pm 1.226$ \\
$\mathrm{As}$ & - \\
$\mathrm{Sb}$ & - \\
\hline
\end{tabular}

Results are expressed as the mean of 3 triplicates \pm standard deviation. B. maderaspatensis: Blepharis maderaspatensis, $\mathrm{Cu}$ : Copper, Ni: Nickel, $\mathrm{Pb}$ : Lead, Hg: mercury, Cr: Chromium, Mn: Manganese, Zn: Zinc, Mo: Molybdenum, Co: Cobalt, Fe: Iron, As: Arsenic, Sb: Antimony

outcome, it may be concluded that the plant B. maderaspatensis ( $L$.) Heyne ex Roth which has vast ethnomedicinal values is found to be safe and may not produce metal toxicity on consumption during their therapeutic application, hence, could be used in drug development.

\section{CONCLUSION}

It is indispensable to maintain safety and efficacy of the herbal plants and their products to avoid serious health problems. In general, routine check and frequent analysis of herbal plants are required to avoid the risk of exceeding the intake beyond the tolerance limits as mentioned in the standards. Hence, in the present study, an attempt has been made to analyze the heavy metal composition of B. maderaspatensis (L.) Heyne ex Roth by ICP-OES and thereby ensure the safety and efficacy of its use as a potential herbal medicine.

\section{ACKNOWLEDGMENT}

The authors gratefully acknowledge the technical support extended by Mr. Anand Babu, IIT Kharagpur, Jamshedpur, in the performance of ICP-OES.

\section{AUTHOR'S CONTRIBUTION}

S. Vijayalakshmi, the Principal Investigator, carried out the experiment and wrote the manuscript. K.G Kripa, the Research Supervisor, conceived the original idea, supervised the project and corrected the scientific content of the manuscript.

\section{CONFLICT'S OF INTEREST}

None declared.

\section{REFERENCES}

1. Kaur L, Joseph L, George m. Phytochemical analysis of leaf extract of Aesculus Indica. Int J Pharm Pharm Sci 2011;3:232-4.

2. Singh R, Gautam N, Mishra A, Gupta R. Heavy metals and living systems: An overview. Indian J Pharmacol 2011;43:246-53.

3. World Health Organization. WHO Guidelines for Assessing Quality of Herbal Medicines with Reference to Contaminants and Residues. Geneva: World Health Organization; 2007. p. 1-53.

4. Singh MR. Impurities-Heavy Metals. Spain: IR Prespective; 2007.

5. Brown SE, Welton WC. Heavy Metal Pollution. New York: Nova Science Publishers; 2008.

6. Chibuike GU, Obiora SC. Heavy metal polluted soils: Effect on plants and bioremediation methods. Appl Environ Soil Sci 2014;2014:1-12.

7. Tchounwou PB, Yedjou CG, Patlolla AK, Sutton DJ. Heavy metal toxicity and the environment. EXS 2012;101:133-64.doi:10.1007/9783-7643-8340-4-6.
8. Theron AJ, Tintinger GR, Anderson R. Harmful interactions of nonessential heavy metals with cells of the innate immune system. J Clinic Toxicol 2012;3:1-10.

9. Chowdhury BA, Chandra RK. Biological and health implications of toxic heavy metal and essential trace element interactions. Prog Food Nutr Sci 1987;11:55-113.

10. Boyer T. Ayurveda Medicine and Supplement Hidden Dangers: Arsenic, Lead and Mercury.Available from: https://www.Emaxhealth. com/. [Last accessed on 2012 May 2].

11. Ganesan S, Ramar PN, Banumathi N. Ethnomedicinal survey of Alagarkoil hills (reserved forest) Tamil Nadu, India. Electron J Indian Med 2007;1:11-9.

12. Blepharis maderaspatensis, Dudhiya choti, Kooravaalchedi. Available from: http://www.medplants.blogspot.in/2015/04/blepharismaderaspatensis-dudhiya-choti.html. [Last accessed on 2015 April 11].

13. Suriyavathana M, Indupriya S, Subha P. Preliminary phytochemical screening and antioxidant potential of Blepharis maderaspatensis $(\mathrm{L}$. B. Heyne ex Roth leaf. World J Pharm Pharm Sci 2014;3:658-68.

14. Devarajan ND, Ramalingam S, Subramaniam SM. Gas chromatography mass spectroscopy chromatogram and antimicrobial activity of leaf extracts of Blepharis maderaspatensis and Maesa indica. J Herbs Spices Med Plants 2014;21:267-82

15. Vijayalakshmi S, Kripa KG. Therapeutic uses of plants of genus Blepharis-a systematic review. Int J Pharm Bio Sci 2016;7:236-43.

16. Koldabadi SG, Ruchi V, Bhaskar KV, Lalit K. Heavy metals in environment, living systems and herbal preparation: An overview. Int Resb J Pharm 2012;3:128-30.

17. Narzary H, Basumatary S. Determination of mineral composition of some wild edible plants consumed by Bodos of Assam, North-East India. J Chem Pharm Res 2017;9:60-4. Available from: http://www. jocpr.com. [Last accessed on 2016 Feb 11]

18. Kripa KG, Sangeetha R, Chamundeeswari D. Pharmacognostical and physicochemical evaluation of the plant Leucas aspera. Asian J Pharm Clin Res 2016;9:263-68.

19. Mallya R, Bhitre MJ. Pharmacognostic standardisation and chromatographic fingerprinting of leaves and fruits of Zanthoxylum Rhetsa. Int J Pharm Pharm Sci 2018;10:101-4.

20. Zaprjanova PS, Angelova GL, Bekjarov KI, Ivanov AA, ICP. Determination of heavy metal content in tobacco, Bulgarian. J Agric Sci 2006;12:537-51.

21. Reichert U, Sehat N. Metal Residue: How Much is Too Much? To Comply with Evolving Guidelines, Drug Makers will Need Analytical and Regulatory Support. Pharmaceutical manufacturing; 2013. Available from: http://www.pharmamanufacturing.com. [Last accessed on 2017 Jun 1].

22. Stanojkovic-sebic A, Pivic R, Josic D, Dinic Z, Stanojkovi A. Heavy metals content in selected medicinal plants commonly used as components for herbal formulations. J Agric Sci 2015;21:317-25.

23. Emst E. Toxic heavy metals and undeclared drugs in Asian herbal medicines. Trends Pharmacol Sci 2002;23:136-9.

24. Shaban NS, Abdou KA, Hassan NE. Impact of toxic heavy metals and pesticide residues in herbal products. J Basic Appl Sci 2016;5:1-5.

25. The American Herbal Products Association. Heavy Metals: Analysis and Limits in Herbal Dietary Supplements. The American Herbal Products Association; 2009. p. 12-3. Available from: http://www. naturalhealthresearch.org/. [Last accessed on 2017 May 15].

26. World Health Organization. Childhood Lead Poisoning. World Health Organization; 2010. p. 11-54. Avilable from: http://www.who.int/. [Last accessed on 2017 Jan 29].

27. Mercury, Vermont Legislative Research Shop, The University of Vermont. Available from: http://www.uvm.edu/ vlrs/doc/mercury.htm. [Last accessed on 2017 Jan 20].

28. Saha JC, Dikshit AK, Bandyopadhyay M, Saha KC. A Review of Arsenic Poisoning and its Effects on Human Health; 2014. p. 1-38. Available from: https://www.epa.gov/sites/production/files/2014-03/ documents/. [Last accessed on 2017 Jan 17].

29. Saper RB, Kales SN, Paquin J, Burns MJ, Eisenberg DM, Davis RB, et al. Heavy metal content of ayurvedic herbal medicine products. JAMA 2004;292:2868-73.

30. Dghaim R, Al Khatib S, Rasool H, Khan A. Determination of heavy metal concentration in traditional herbs commonly consumed in the United Arab Emirates. J Environ Public Health 2015;2015:1-6. 